\title{
Implementasi Program Kemitraan dan Program Bina Lingkungan Pada PT. PELINDO III Surabaya
}

\author{
Andrianto \\ Fakultas Ekonomi, Universitas Muhammadiyah Surabaya, Indonesia \\ Email: andrianto914@yahoo.com
}

\begin{abstract}
Abstraksi
Program Tanggung Jawab Sosial Perusahaan yang telah dijalankan oleh PT. Pelindo III Surabaya, diwujudkan dalam bentuk program kemitraan dan program pengembangan lingkungan hidup. Program Kemitraan merupakan program yang diluncurkan oleh pemerintah sebagai bentuk kepedulian dan tanggung jawab Badan Usaha Milik Negara (BUMN) terhadap pembangunan ekonomi khususnya usaha kecil di lingkungan perusahaan, sedangkan program pengembangan lingkungan merupakan program yang menjadi perhatian PT. Pelindo III (Persero) yang merupakan salah satu perusahaan BUMN dalam menghadapi kondisi sosial masyarakat sekitar perusahaan. Penelitian ini merupakan penelitian kuantitatif deskriptif,dimana penelitian ini untuk mempelajari dan menjelaskan tentang kedua program CSR yang telah dijalankan oleh PT. Pelindo III (Persero).Dari hasil penelitian, dapat disimpulkan bahwa baik program CSR yang telah dijalankan oleh PT. Pelindo III (Persero) sangat bagus dan terprogram. Hal ini dibuktikan dengan adanya program kerja setiap tahun dalam pelaksanaannya disertai adanya laporan posisi dan aktivitas keuangan tentang program kemitraan dan pengembangan lingkungan. Jadi dalam penyusunan informasi keuangan dan pelaksanaan praktik kedua program tersebut telah sangat memenuhi unsur transparansi.
\end{abstract}

Kata kunci: Corporate Social Responsibility (CSR), Program Kerja, Organisasi Bisnis, Transparansi

\begin{abstract}
Corporate Social Responsibility Program which has been run by PT. Pelindo III Surabaya, realized in the form of partnership program and environmental development program. Partnership Program is a program launched by the government as a form of awareness and responsibility of State Owned Enterprises (BUMN) to economic development, especially small business in the company environment, while environmental development program is a program that concerns PT. Pelindo III (Persero), which is one of the state-owned enterprises in facing the social conditions of the community around the company. This research is a quantitative descriptive research with case study approach to study and explain about both CSR programs that have been run by PT. Pelindo III (Persero). From the results of research, it can be concluded that both CSR programs that have been run by PT. Pelindo III (Persero) is very good and programmed. This is evidenced by the existence of work programs every year in its implementation accompanied by a report on the position and financial activities of the partnership program and
\end{abstract}


environmental development. So in the preparation of financial information and implementation of the practice both programs have been very fulfilling elements of transparency.

Keywords: Corporate Social Responsibility (CSR), Work Program, Business Organization, Transparency

\section{Pendahuluan}

Aktifitas dalam dunia bisnis sekarang selalu dihadapkan dalam kondisi yang membingungkan. Di satu sisi perusahaan harus mencari keuntungan yang besar, di sisi lain perusahaan harus memberi tanggung jawab sosial atau corporate sosial responsibility kepada masyarakat dan lingkungan sekitar sebagai bentuk pembangunan berkelanjutan. Hal tersebut membuat para management harus lebih aktif lagi guna mencari keuntungan dalam kegiatan operasional perusahaan. Corporate Sosial Responsibility (CSR) sebagai tanggung jawab sosial perusahaan mengingat perusahaan tersebut berdiri dan melakukan kegiatan operasional di sekitar wilayah masyarakat. Selain itu, CSR sebagai tanggung jawab sosial perusahaan akibat kemiskinan, kerusakan lingkungan, pencemaran lingkungan sekitar perusahaan yang terus menerus meningkat seiring berlangsungnya kegiatan operasional perusahaan. Oleh karenanya, CSR sebagai penstabil efek dari kegiatan operasional yang dihasilkan perusahaan agar masyarakat sekitar dapat merasakan pula keuntungan dari berdirinya perusahaan di wilayahnya.

Corporate Sosial Responsibility (CSR) menjadi program perusahaan sebagai pembangunan berkelanjutan perusahaan sendiri. Corporate Sosial Responsibility (CSR) sendiri secara sederhana merupakan suatu konsep serta tindakan yang dilakukan oleh suatu perusahaan yang bertujuan profit baik perusahaan yang merupakan kepemilikan swasta maupun milik negara dalam mewujudkan keberadaannya dengan upaya memberikan tanggung jawab sosial serta lingkungan dimana perusahaan itu berdiri. Dalam hal tersebut, gagasan CSR menekankan bahwa perusahaan tak hanya memfokuskan diri untuk mencari laba besar, namun perusahaan juga harus membangun 
program CSR yang tertuju pada masyarakat dan lingkungan sekitar sesuai dengan ketetapan perusahaan tersendiri.

Di Indonesia sendiri berbicara mengenai regulasi tentang pelaksanaan CSR ada tujuh regulasi yang mengaturnya, yaitu yang pertama Peraturan yang mengikat Badan Usaha Milik Negara (BUMN), sebagaimana Keputusan Menteri BUMN Per-05/MBU/2007 tentang Program Kemitraan Bina Lingkungan (PKBL). PKBL terdiri program perkuatan usaha kecil melalui pemberian pinjaman dana bergulir dan pendampingan (disebut Program Kemitraan), serta program pemberdayaan kondisi sosial masyarakat sekitar (disebut Program Bina Lingkungan), dengan dana kegiatan yang bersumber dari laba BUMN. Kedua, Peraturan mengikat Perseroan Terbatas (PT) yang operasionalnya terkait Sumber Daya Alam (SDA), yaitu Undang-Undang Perseroan Terbatas Nomor 40 Tahun 2007. Dalam pasal 74 disebutkan: (1) Perseroan yang menjalankan kegiatan usahanya di bidang dan/atau berkaitan dengan sumber daya alam, wajib melaksanakan Tanggung Jawab Sosial dan Lingkungan, (2) Tanggung Jawab Sosial dan Lingkungan sebagaimana dimaksud ayat (1) merupakan kewajiban Perseroan yang dianggarkan dan diperhitungkan sebagai biaya Perseroan yang pelaksanaannya dilakukan dengan memperhatikan kepatutan dan kewajaran. Ketiga, Peraturan Pemerintah (PP) Nomor 47 Tahun 2012 Tentang Tanggungjawab Sosial dan Lingkungan. PP ini melaksanakan ketentuan Pasal 74 Undang-Undang Nomor 40 Tahun 2007 . Dalam PP ini, perseroan yang kegiatan usahanya di bidang dan/atau berkaitan dengan sumber daya alam diwajibkan untuk melaksanakan tanggung jawab sosial dan lingkungan. Kegiatan dalam memenuhi kewajiban tanggung jawab sosial dan lingkungan tersebut harus dianggarkan dan diperhitungkan sebagai biaya Perseroan yang dilaksanakan dengan memperhatikan kepatutan dan kewajaran. Keempat, Peraturan yang mengikat jenis perusahaan penanaman modal, yaitu Undang-Undang Penanaman Modal Nomor 25 Tahun 2007. Dalam Pasal 15 (b) dinyatakan bahwa "Setiap penanam modal berkewajiban melaksanakan tanggung jawab sosial perusahaan". Sanksi-sanksi, diatur dalam Pasal 34, berupa sanksi administratif dan sanksi lainnya, diantaranya: (a) Peringatan tertulis; (b) 
pembatasan kegiatan usaha; (c) pembekuan kegiatan usaha dan/atau fasilitas penanaman modal; atau (d) pencabutan kegiatan usaha dan/atau fasilitas penanaman modal. Kelima, Peraturan CSR bagi perusahaan pengelola Minyak dan Gas (Migas), diatur dalam Undang-Undang Minyak dan Gas Bumi Nomor 22 Tahun 2001. Dalam pasal 13 ayat 3 (p) disebutkan: Kontrak Kerja Sama sebagaimana dimaksud dalam ayat (1) wajib memuat paling sedikit ketentuan-ketentuan pokok yaitu: (p) pengembangan masyarakat sekitarnya dan jaminan hak-hak masyarakat adat". Keenam, Undang-undang Nomor 13 Tahun 2011 Tentang Penanganan Fakir Miskin, Undang-undang ini tidak membahas secara khusus peran dan fungsi perusahaan dalam menangani fakir miskin, melainkan terdapat klausul dalam pasal 36 ayat 1 "Sumber pendanaan dalam penanganan fakir miskin, meliputi: c. dana yang disisihkan dari perusahaan perseroan. Diperjelas dalam ayat 2 Dana yang disisihkan dari perusahaan perseroan sebagaimana dimaksud pada ayat (1) huruf digunakan sebesar-besarnya untuk penanganan fakir miskin. Sedangkan pada Pasal 41 tentang "Peran Serta Masyarakat", dalam ayat 3 dijelaskan bahwa "Pelaku usaha sebagaimana dimaksud pada ayat (2) huruf j berperan serta dalam menyediakan dana pengembangan masyarakat sebagai pewujudan dari tanggung jawab sosial terhadap penanganan fakir miskin. Ketujuh, Peraturan Menteri Sosial RI Nomor 13 Tahun 2012 tentang Forum tanggungjawab dunia usaha dalam penyelenggaraan Kesejehteraan Sosial. "Kementrian Sosial memandang penting dibentuknya forum CSR pada level Provinsi, sebagai sarana kemitraan antara pemerintah dengan dunia usaha. Rekomendasi Permensos adalah dibentuknya Forum CSR di tingkat provinsi beserta pengisian struktur kepengurusan yang dikukuhkan oleh Gubernur". ( Sumber : www.rahmatullah.net)

Penelitian ini merupakan pengembangan dari penelitian yang menyatakan bahwa secara konseptual corporate social responsibility ( CSR ) yang dilakukan oleh suatu perusahaan tidak hanya sebagai tindak lanjut kepedulian dari perusahaan dan lingkungan masyarakat sekitar namun juga sebagai upaya manajerial dalam meningkatkan nilai perusahaan di mata masyarakat sekitar. Sehingga diharapkan ada 
hubungan simbiosis mutualisme antara perusahaan dengan lingkungan masyarakat sekitar. PT. Pelindo III sebagai objek penelitian dari peneliti, merupakan salah satu dari perusahaan Badan Usaha Milik Negara ( BUMN ) yang karena kinerja keuangan dalam bidang corporate social responsibility ( CSR ) langsung dapat dirasakan lingkungan masyarakat sekitar. Budiasih (2015) dalam penelitiannya menyebutkan bahwa "kepemilikan institusional dan komite audit berpengaruh negatif pada nilai perusahaan, sedangkan kepemilikan manajerial dan proporsi dewan komisaris independen tidak memiliki pengaruh pada nilai perusahaan. Selain itu pegungkapan corporate social responsibility tidak mampu memoderasi pengaruh good corporate governance pada nilai perusahaan".

Kirana (2009) dalam penelitiannya juga telah menyebutkan bahwa "pengaturan tentang corporate social responsibility mengandung implikasi dampak sebagai berikut : (1). Pengaturan Corporate Social Responsibility di Indonesia belum mengalami perubahan secara signifikan meskipun bersifat wajib untuk dilaksanakan oleh pelaku usaha atau perusahaan. Hal ini disebabkan karena belum adanya perangkat-perangkat yang mendukung dalam pelaksanaan pengaturan tersebut. Sehingga para pelaku usaha atau perusahaan tidak dapat melaksanakan program-program Corporate Social Responsibility secara optimal.(2). Pelaksanaan program-program Corporate Social Responsibility di Indonesia pada umumnya belum dirasakan sepenuhnya oleh stakeholder disekitar perusahaan". Padahal pelaksanaan program-program tersebut merupakan bentuk perwujudan dari prinsip-prinsip Good Corporate Governance. Pelaksanaan tersebut juga bertujuan untuk mencapai keadilan dan kesejahteraan seluruh komponen yang ada di Indonesia.

Hermawan dan Mafulah (2014) dalam penelitiannya bahwa "secara parsial variabel kinerja keuangan ( return on asset) tidak berpengaruh secara signinfikan terhadap nilai perusahaan.Selanjutnya secara parsial variabel corporate social responsibility mampu memoderasi hubungan hubungan kinerja keuangan terhadap nilai perusahaan". 
Nurlela dan Islahuddin (2008) dalam penelitiannya "Corporate Social Responsibility, prosentase kepemilikan manajemen, serta interaksi antara Corporate Social Responsibility dengan prosentase kepemilikan manajemen secara simultan bepengaruh signifikan terhadap nilai perusahaan. Sedangkan secara parsial hanya prosentase kepemilikan manajemen dan interaksi antara Corporate Social Responsibility dengan prosentase kepemilikan manajemen yang berpengaruh signifikan terhadap nilai perusahaan sedangkan variabel lainnya yang terdapat dalam penelitian ini tidak berpengaruh signifikan terhadap nilai perusahaan".

Tujuan Penelitian Untuk mengetahui implementasi Program Kemitraan dan Bina Lingkungan pada PT. PELINDO III ( Persero )Surabaya

\section{Kerangka Konseptual}

Sumber : Diolah Penulis

Identifikasi Kegiatan Program Kemitraan dan Bina Lingkungan

Pada PT. Pelindo III Surabaya

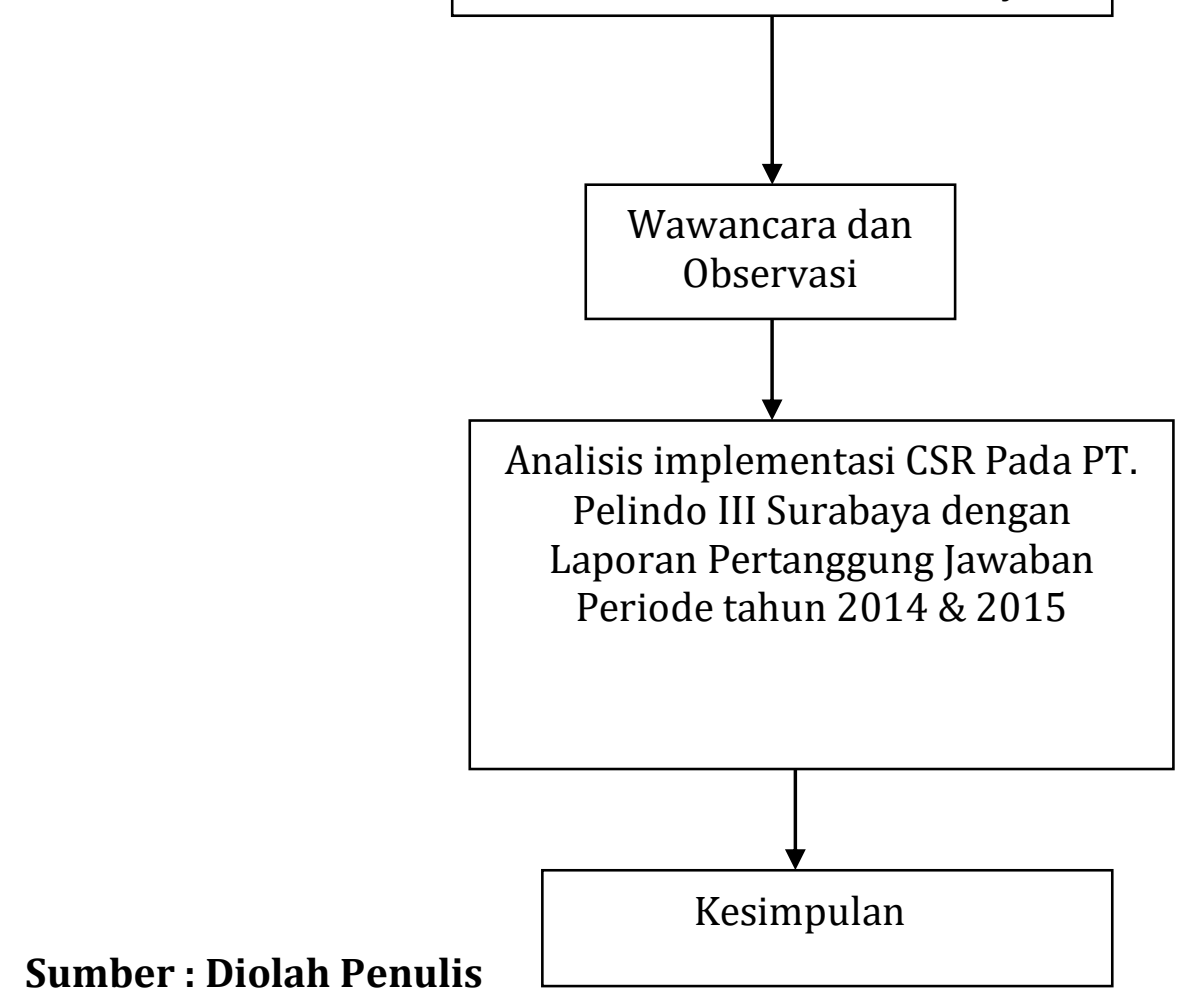




\section{Metode Penelitian}

\section{Pendekatan Penelitian dan Data Penelitian}

Dalam melakukan penelitian, penulis menggunakan pendekatan penelitian yang yang bersifat kuantitatif dengan tipe kuantitatif deskriptif terhadap implementasi Program Kemitraan dan Bina Lingkungan yang telah dijalankan oleh PT. Pelindo III Surabaya yang telah tertuang dalam laporan Pertanggung jawaban Kegiatan Program Kemitraan dan Bina Lingkungan periode tahun 2015.

Dalam penelitian ini, peneliti menggunakan data yang berupa data primer yaitu data yang bersumber langsung dari informan peneliti yang telah terjun di lapangan dengan melakukan wawancara pada bagian keuangan PT. Pelindo III Surabaya, dan data sekunder dalam penelitian ini adalah berupa dokumen-dokumen yang berasal dari PT. Pelindo III Surabaya yang terkait dengan program CSR periode tahun 2015,Laporan keuangan program kemitraan dan bina lingkungan PT. Pelindo III periode tahun 2014 dan 2015 serta buku-buku referensi dan artikel-artikel yang terkait dengan penelitian CSR.

\section{Ruang Lingkup Penelitian}

Adapun yang menjadi ruang lingkup penelitian adalah di PT. Pelindo III (Persero) yang berlokasi di Tanjung Perak No. 610,Perak Timur -Pabean Cantikan,Surabaya. Dimana di PT. Pelindo III ( Persero ) Surabaya melakukan kegiatan Program Kemitraan dan Program Bina Lingkungan. Untuk tambahan informasi dalam penelitian ini, peneliti memilih bagian keuangan dimana proses untuk penganggaran program kegiatan kemitraan dan bina lingkungan harus melewati bagian keuangan.

\section{Teknik Pengumpulan Data}

Menurut Fatihudin (2015:118) "pengumpulan data adalah tahapan-tahapan atau langkah-langkah yang harus dilalui oleh peneliti bila akan melakukan penelitian. Yang dimaksud tahapan disini adalah tahapan pengumpulan data, informasi, keterangan dari responden yang akan diolah dalam penelitian". Prosedur pengumpulan data merupakan kelengkapan atau penggambaran metode yang dipilih, agar dapat 
dikumpulkan,pengumpulan data primer yang digunakan oleh peneliti dalam penelitian ini dilakukan dengan langkah-langkah sebagai berikut :

1. Wawancara, yaitu mengumpulkan data dengan wawancara langsung dengan pihak manajemen yang terkait langsung dengan penelitian ini yaitu di bagian keuangan PT. Pelindo III ( Persero ) Surabaya.

2. Observasi, yaitu mendapatkan data dengan cara mengadakan pengamatan secara langsung kepada obyek yang diteliti yang meliputi keadaan lapangan obyek penelitian yaitu PT. Pelindo III Surabaya.

3. Dokumentasi, yaitu dengan cara meminta data dari lapora-laporan dan catatan milik kantor yang erat hubungannya dengan penyusunan laporan penelitian ini yang terdiri dari Laporan keuangan program kemitraan dan bina lingkungan PT. Pelindo III periode tahun 2014 dan 2015.

\section{Teknik Pengolahan Data dan Analisis Data}

Menurut Fatihudin (2015:133) “Teknik pengolahan data dalam suatu penelitian adalah langkah berikutnya setelah pengumpulan data dilakukan". Analisis data adalah proses mencari dan menyusun secara sistematis data yang diperleh dari wawancara, catatan lapangan, dan dokumentasi dengan cara mengorganisasikan data kedalam kategori, menjabarkan kedalam unit-unit, melakukan sintesa, menyusun kedalam pola, memilih mana yang penting untuk dipelajari dan membuat kesimpulan sehingga mudah dipahami oleh diri sendiri maupun orang lain.

Teknik analisis data dari penelitian ini adalah sebagai berikut:

1. Melakukan studi lapangan di PT. Pelindo III (Persero) untuk bertujuan mengetahui secara langsung bentuk-bentuk kegiatan program kemitraan dan bina lingkungan yang telah dijalankan oleh PT. Pelindo III (Persero).

2. Melakukan wawancara dengan pihak bagian keuangan PT. Pelindo III (Persero) dengan tujuan untuk mendapatkan informasi seputar program kemitraan dan bina lingkungan PT. Pelindo III serta mendapatkan informasi 
juga terkait dengan kinerja keuangan perusahaan PT. Pelindo III dalam menjalankan program kemitraan dan bina lingkungan.

3. Melakukan analisis data atas kegiatan wawancara dengan bagian keuangan PT. Pelindo III, serta melakukan analisis data terhadap kegiatan kinerja keuangan yang berkaitan dengan program kemitraan dan bina lingkungan.

4. Memberikan deskriptif penjelasan atas analisis data kinerja keuangan yang berkaitan dengan program kemitraan dan bina lingkungan PT. Pelindo III (Persero).

\section{Hasil Dan Pembahasan}

Program CSR PT PELINDO III Pusat dapat dikatakan sangat banyak. Hal tersebut dapat dilihat dalam buku Laporan Manajemen dan Laporan Keuangan PKBL tahun 2015 setelah audit. Dalam Departemen PKBL sendiri memiliki program kerja yang terfokus pada masyarakat dan lingkungan sekitar perusahaan. Program kerja tersebut disesuaikan dengan Peraturan Menteri Badan Usaha Milik Negara Republik Indonesia No. 03/MBU/12/2016 tentang Perubahan Atas Peraturan Menteri Badan Usaha Milik Negara No. 09/MBU/07/2015 tentang Program Kemitraan dan Program Bina Lingkungan Badan Usaha Milik Negara ( sumber: PT. Pelindo III). Tertulis dalam pasal 9 Ayat 3 yang berbunyi Dana Program Bina Lingkungan disalurkan dalam bentuk : a. Bantuan korban bencana alam; b. Bantuan pendidikan dan atau pelatihan; c. Bantuan peningkatan kesehatan; d. Bantuan pengembangan prasarana dan/atau sarana umum; e. Bantuan sarana ibadah; f. Bantuan sosial kemasyarakatan dalam rangka pengentasan kemiskinan ( Sumber: PT. Pelindo III).

Program Corporate Social Responsibility yang telah dijalankan oleh PT. Pelindo III Surabaya, diwujudkan dalam bentuk program kemitraan dan program bina lingkungan. Program kemitraan merupakan program yang dicanangkan pemerintah sebagai wujud kepedulian dan tanggung jawab Badan Usaha Milik Negara ( BUMN) terhadap perkembangan perekonomian, terutama bagi usaha kecil di lingkungan perusahaan, sedangkan program bina lingkungan merupakan program bentuk kepedulian PT. 
Pelindo III ( Persero ) terhadap kondisi sosial masyarakat sekitar perusahaan (Sumber : PT. Pelindo III).

Dalam pelaksanaan kedua program tersebut, PT. Pelindo III ( persero ) telah menetapkan mekanisme penyaluran program kemitraan dan bina lingkungan adalah dilakukan dengan metode perantara tak langsung atau yang disebut juga dengan metode chanelling yaitu penyaluran langsung oleh Pembina kepada para calon mitra binaan atau calon penerima bantuan berdasarkan proposal yang masuk, sebagaimana berikut (sumber PT. Pelindo III) :

\section{Program Kemitraan PT. Pelindo III}

1. Penyampaian proposal ditujukan kepada General Manager kantor Cabang PT. Pelindo III.

2. Pemeriksaan secara administratif merupakan pemeriksaan terhadap proposal yang akan diajukan oleh calon mitra binaan terhadap pemenuhan persyaratan dan kelengkapan berkas.

3. Setelah dilakukan pemeriksaan administrasi, maka selanjutnya dilakukan survey lapangan untuk menguji kebenaran data yang disajikan dalam proposal pengajuan calon mitra nasabah dengan mengevaluasi calon mitra Binaan dengan formula penilaian Personality dan 5 C ( Character, Capacity, Capital,Colateral, Conditions ).

4. Setelah dilakukan survey terhadap kebenaran data baik secara administrasi maupun secara personality ,kemudian kantor cabang Pembina menyampaikan laporan hasil survey tersebut ke kantor pusat disertai dengan tambahan usulan besaran dana yang akan disalurkan kepada masing-masing calon mitra binaan.

5. Setelah Kantor Pusat menerima hasil laporan survey dari kantor cabang Pembina disertai dengan adanya usulan terkait besaran dana yang akan disalurkan kepada masing -masing calon mitra binaan, maka selanjutnya Kantor pusat memberikan 
persetujuan dan diterbitkan Surat Kuasa dari Direksi kepada General Manager Cabang penyalur untuk melaksanakan penandatanganan Surat Perjanjian Pinjaman dengan Calon Mitra Binaan.

\section{Program Bina Lingkungan PT. Pelindo III (Persero)}

1. Dalam program bina lingkungan penyaluran dana dilakukan oleh kantor pusat dan / atau cabang.

2. Untuk pengajuan proposal dari calon mitra binaan ditujukan kepada General manager Cabang Pelabuhan yang terdekat dengan lokasi objek, untuk kemudian dilakukan pemeriksaan terhadap berkas administrasi dan setelah dilakukan pemeriksaan terhadap berkas administrasi kemudian dilakukan survey lapangan dengan atau tanpa petugas dari kantor pusat guna mengecek kebenaran atas kondisi dan kebutuhan utama dari objek calon mitra binaan yang akan dibantu.

3. Setelah dilakukan pengecekan terhadap persyaratan administrasi dan survey ke lapangan, General manager cabang Pelabuhan menyampaikan hasil survey dan usulan besaran dana untuk masing-masing objek dari calon mitra binan untuk dimintakan persetujuan Direksi.

4. Setelah mendapat persetujuan dari Direksi terhadap pengajuan dana bina lingkungan, maka setelah itu dilakukan penyaluran dana program bina lingkungan, adapun penyaluran dilaksanakan di masing-masing cabang penyalur yang terdekat dengan lokasi penerima bantuan maupun melalui kantor pusat untuk wilayah Jawa Timur.

Secara lebih ringkas, gambaran umum mengenai realisasi pelaksanaan program kerja dalam program kemitraan Manajemen PT. Pelindo III ( persero ) sampai dengan tahun 2015, dapat dilihat pada tabel dibawah ini : 
Tabel 1

Realisasi Pelaksanaan Program Kerja dalam Program Kemitraan PT. Pelindo III ( Persero) Tahun 2015

\begin{tabular}{|c|c|c|}
\hline No & Program kerja & Realisasi \\
\hline 1 & $\begin{array}{l}\text { Penyusunan Revisi Pedoman } \\
\text { PKBL }\end{array}$ & Telah disusun d triwulan IV 2015 \\
\hline 2 & Sosialisasi Pedoman PKBL & $\begin{array}{l}\text { Telah dilaksanakan di Bulan Januari } \\
2016 .\end{array}$ \\
\hline 3 & $\begin{array}{l}\text { Penyaluran pinjaman pada mitra } \\
\text { binaan }\end{array}$ & $\begin{array}{l}\text { Telah dilaksanakan penyaluran kepada } \\
325 \text { mitra binaan pada Cabang } \\
\text { Tanjung Perak,Cabang Tanjung } \\
\text { Emas,Cabang Tanjung Intan,Cabang } \\
\text { Benoa, Cabang Banjarmasin, dan } \\
\text { Cabang Tanjung Wangi. }\end{array}$ \\
\hline 4 & $\begin{array}{l}\text { Pelatihan dan Pameran bagi mitra } \\
\text { binaan }\end{array}$ & $\begin{array}{l}\text { Telah dilaksanakan Diklat manajemen } \\
\text { tingkat dasar dan kewirausahaan pada } \\
325 \text { mitra binaan, pelatihan } \\
\text { peningkatan kualitas kain sasirangan } \\
\text { pada pengusaha kain sasirangan Mitra } \\
\text { Binaan cabang Banjarmasin serta } \\
\text { sebanyak } 33 \text { mitra binaan telah } \\
\text { diikutsertakan pada } 9 \text { pameran yang } \\
\text { diikuti oleh Pelindo III }\end{array}$ \\
\hline
\end{tabular}

\section{Sumber : PT. Pelindo III ( Persero )}

Sedangkan untuk program bina lingkungan periode tahun 2015 yang telah dijalankan oleh PT. Pelindo III Surabaya oleh peneliti akan dijelaskan dibawah ini :

1. Penanganan bantuan korban bencana alam : dengan memberikan bantuan korban bencana alam banjir luapan kali lamong di daerah Gresik Jawa Timur dan bantuan untuk banjir di tegowanu Kabupaten Grobogan Jawa Tengah, serta partisipasi perusahaan untuk bantuan posko evakuasi jorban bencana jatuhnya peswawat AirAsia di cabang Kumai Kalimantan Tengah.

2. Pendidikan dan atau pelatihan : melaksanakan pelatihan pemandian jenazah serta pelatihan keterampilan pembuatan kerajinan berbahan dasar enceng gondok di Desa Sumput Kecamatan Diyorejo Kabutan Gresik, serta telah melaksanakan penyaluran bantuan pendidikan dan pelatihan di daerah Surabaya dan sekitarnya, 
seperti di Cabang Gresik, Cabang Probolinggo, Cabang Kupang, Cabang Banjarmasin, Cabang Kumai dan Cabang Benoa.

3. Peningkatan Kesehatan : telah meningkatkan Kesehatan Masyarakat Sekitar, seperti sunatan massal di Cabang Tanjung Intan dan Celukan Bawang, operasi katarak di Cabang Banjarmasin serta bakti sosial untuk masyarakat berupa operasi bibir sumbing gratis di NTB dan Probolinggo seta PT PELINDO III juga telah memberikan bantuan berupa pemberian masker gratis untuk bencana asap yang bekerjasama dengan BNPB.

4. Bantuan Sarana dan Prasarana Umum : telah melaksanakan bantuan kepada Himpunana Nelayan di Kabupaten Gresik, bantuan pembuatan bank sampah di Kampung Lawas Maspati Kelurahan Bubutan Kota Surabaya dan Kota Pasuruan, serta memberikan bantuan berupa gerobak sampah kepada Pemerintah Kabupaten Gresik. PT PELINDO III juga telah merenovasi Fasum Mandi Cuci Kaku (MCK) di tempat Pelelangan Ikan Bale Gede Gresik, serta memberikan bantuan berupa 20 unit gerobak PK5 di Tanjung Perak Surabaya.

5. Bantuan Sarana Ibadah : telah memberikan bantuan rehabilitasi masjid di Semarang dan Banjarmasin serta telah melaksanakan penyaluran bantuan sarana ibadah di seluruh cabang PT PELINDO III.

6. Ketahanan Pangan : Pembagian sembako gratis bagi masyarakat kurang mampu di sekitar wilayah perusahaan di Cabang Bima, Cabang Tanjung Emas,Cabang Banjarmasin,Cabang Kotabaru,Cabang Lembar.

7. Bantuan Pelestarian Alam : telah memberikan bantuan untuk melestarikan alam sekitar berupa pelestarian terumbu karang di Gili Labak Madura, dan penanaman mangrove di Cabang Probolinggo dan pulau Galang, penanaman mangrove juga dilakukan PT PELINDO III di Surabaya serta di Cabang Lembar. 
Dari semua kegiatan bina lingkungan yang telah dilaksanakan oleh PT. Pelindo III Surabaya, dapat disusun dalam bentuk laporan realisasi penyaluran dana bina lingkungan dari tahun 2014 sampai dengan tahun 2015.

\section{Tabel 2}

Laporan Realisasi Akumulasi Penyaluran Dana Bina Lingkungan

PT. Pelindo III ( Persero ) Surabaya

Tahun 2014 \& Tahun 2015

\begin{tabular}{|c|c|c|c|c|}
\hline No & Uraian & s.d Thn 2015 & $\begin{array}{l}\text { Penyaluran } \\
\text { tahun } 2015\end{array}$ & s.d Thn 2014 \\
\hline 1 & Korban bencana alam & $3,930,009,050$ & $185,155,000$ & $3,744,854,050$ \\
\hline 2 & Pendidikan dan atau pelatihan & $20,280,186,493$ & $1,759,409,000$ & $18,520,777,493$ \\
\hline 3 & Peningkatan kesehatan & $4,992,374,120$ & $1,036,640,000$ & $3,955,734,120$ \\
\hline 4 & Sarana dan Prasarana Umum & $27,987,437,150$ & $2,341,311,650$ & $25,646,125,500$ \\
\hline 5 & Sarana Ibadah & $35,450,895,364$ & $2,178,186,200$ & $33,272,709,164$ \\
\hline 6 & Program Ketahanan Pangan & $1,199,325,525$ & - & $1,199,325,525$ \\
\hline 7 & Pelestarian Alam & $2,760,637,500$ & $199,300,000$ & $2,561,337,500$ \\
\hline 8 & Pengentasan Kemiskinan & $6,456,648,902$ & $3,073,362,300$ & $3,383,286,602$ \\
\hline 9 & $\begin{array}{l}\text { Bantuan pendidikan,Pelatihan } \\
\text { Mitra binaan }\end{array}$ & $495,407,800$ & $495,407,800$ & - \\
\hline & Sub Jumlah & $103,552,921,904$ & $11,268,771,950$ & $92,284,149,954$ \\
\hline
\end{tabular}

\section{Sumber : PT. Pelindo III Surabaya}

Disamping laporan realisasi akumulasi penyaluran dana kemitraan dan bina lingkungan,

PT. Pelindo III juga telah menyusun laporan posisi keuangan dan laporan aktivitas terkait dengan program kemitraan dan bina lingkungan PT. Pelindo III, seperti yang terlihat dibawah ini. 
Tabel 3

Laporan Posisi Keuangan

Program Kemitraan dan Bina Lingkungan PT. Pelindo III ( Persero )

Periode tahun 2015

\begin{tabular}{|c|c|c|}
\hline URAIAN & 31 Des 2015 & 31 Des 2014 \\
\hline \multirow{2}{*}{\multicolumn{3}{|c|}{$\begin{array}{l}\text { Aset : } \\
\text { Aset lancar : }\end{array}$}} \\
\hline & & \\
\hline Kas dan setara kas & $25,991,485,739$ & $47,877,249,395$ \\
\hline Deposito & $43,000,000,000$ & $6,000,000,000$ \\
\hline Piutang Kepada BUMN Pembina Lain /Lembaga Penyalur & $10,125,000,000$ & $10,375,000,000$ \\
\hline Piutang Mitra Binaan & $27,788,957,080$ & $26,523,098,961$ \\
\hline Piutang Jasa Administrasi & $120,904,500$ & $244,747,111$ \\
\hline Akm. Penyih. Piutang MB & $(23,015,899,807)$ & $(21,207,970,972)$ \\
\hline Akm. Penyih. Piutang jasa administrasi & $(81,747,844)$ & $(18,786,929)$ \\
\hline Piutang Netto & $14,937,213,929$ & $15,916,088,171$ \\
\hline Uang Muka & $4,721,000$ & $498,061,200$ \\
\hline Pendapatan Yang Akan Diterima & $76,551,481$ & $14,465,748$ \\
\hline Jumlah Aset Lancar & $84,009,972,149$ & $70,305,864,514$ \\
\hline Aset Tetap : & & \\
\hline Harga Perolehan & $1,136,944,620$ & $1,136,944,620$ \\
\hline Akumulasi Penyusutan & $(812,063,215)$ & $(712,499,556)$ \\
\hline Aset tetap bersih & $324,881,405$ & $424,445,064$ \\
\hline Aset Lain-lain : & & \\
\hline Piutang Bermasalah & $39,001,697,726$ & $39,223,291,160$ \\
\hline Akm. Penyih. Piutang Bermasalah & $(39,001,697,726)$ & $(39,223,291,160)$ \\
\hline Piutang Bermasalah Netto & & \\
\hline IUMLAH ASET & $84,334,853,554$ & $70,730,309,578$ \\
\hline
\end{tabular}




\section{LIABILITAS DAN ASET NETO}

Liabilitas :

Liabilitas jangka pendek :

$72,593,600$

$527,960,058$

Beban Ymh Dibayar

$967,325,179$

$1,524,978,188$

Angsuran belum teridentifikasi

Jumlah Liabilitas Jangka Pendek

Liabilitas Jangka Panjang

Hutang Jk. Panjang

Jumlah Liabilitas Jangka Panjang

Aset Neto :

Aset neto tidak terikat

$83,294,934,775$

$68,677,371,333$

Aset neto terikat

Jumlah Aset Neto

\begin{tabular}{|l|c|}
\hline- & - \\
\hline $83,294,934,775$ & $68,677,371,333$ \\
\hline $\mathbf{8 4 , 3 3 4 , 8 5 3 , 5 5 4}$ & $\mathbf{7 0 , 7 3 0 , 3 0 9 , 5 7 9}$ \\
\hline
\end{tabular}

JUMLAH LIABILITAS DAN ASET NETO

Sumber : PT. Pelindo III ( Persero )

Tabel 4

Laporan Aktivitas

Program Kemitraan dan Bina Lingkungan PT. PELINDO III ( Persero )

Periode Tahun 2015

\begin{tabular}{|l|l|c|}
\hline \multicolumn{1}{|c|}{ URAIAN } & 31 Des 2015 & 31 Des 2014 \\
\hline PERUBAHAN ASET NETO TIDAK TERIKAT & & \\
PENDAPATAN & & \\
Sumber Alokasi bagian dari laba BUMN Pembina & $23,880,315,340$ & \\
Alokasi sumber dana dari BUMN Pembina & - & $32,449,600,000$ \\
Penerimaan pelimpahan dana dari Unit PKBL lain & $573,715,427$ & -
\end{tabular}


Penggantian Biaya Operasional

Sumbangan

Pendapatan jasa administrasi pinjaman

$1,151,147,253$

$1,271,267,263$

Pendapatan jasa bank

$2,553,699,434$

$781,522,145$

Pendapatan lain-lain

\section{Jumlah}

Alokasi BUMN Peduli dan Aset neto Terikat Temporer yang berakhir pembatasannya

\section{Jumlah}

\section{JUMLAH PENDAPATAN BEBAN}

Beban pembinaan kemitraan

Penyaluran -Bina Lingkungan

beban pembinaan lingkungan

beban Bahan

Beban administrasi

Beban pemeliharaan

Beban Sewa

Beban Umum

Beban Penyusutan Aktiva tetap

Beban penyisihan piutang

Beban Pajak

Beban administrasi Bank

Beban dan pengeluaran lainnya

JUMLAH BEBAN

\begin{tabular}{|c|c|}
\hline - & - \\
\hline - & - \\
\hline $1,151,147,253$ & $1,271,267,263$ \\
\hline $2,553,699,434$ & $781,522,145$ \\
\hline $828,126,523$ & $2,335,719,535$ \\
\hline $28,987,003,977$ & $36,838,108,943$ \\
\hline - & - \\
\hline $28,987,003,977$ & $36,838,108,943$ \\
\hline $435,204,299$ & $1,338,016,771$ \\
\hline $11,268,771,950$ & $12,539,810,800$ \\
\hline $72,072,454$ & $304,860,877$ \\
\hline $22,013,521$ & $31,203,548$ \\
\hline $44,408,290$ & $85,415,585$ \\
\hline $25,386,932$ & $49,223,602$ \\
\hline $1,300,000$ & $48,680,082$ \\
\hline $277,081,013$ & $1,384,225,587$ \\
\hline $99,563,659$ & $98,174,269$ \\
\hline $1,875,368,750$ & $12,303,179,018$ \\
\hline - & - \\
\hline $7,460,569$ & $22,922,216$ \\
\hline $240,809,098$ & $2,066,234,420$ \\
\hline $14,369,440,535$ & $30,271,946,775$ \\
\hline
\end{tabular}




\begin{tabular}{|l|c|c|} 
KENAIKAN ( PENURUNAN ) ASET NETO TIDAK & $\mathbf{1 4 , 6 1 7 , 5 6 3 , 4 4 2}$ & $\mathbf{6 , 5 6 6 , 1 6 2 , 1 6 8}$ \\
\cline { 2 - 3 } TERIKAT & & \\
Kenaikan ( Penurunan ) Aset neto Tidak Terikat & $14,617,563,442$ & $6,566,162,168$ \\
Aset Neto Awal Tidak Terikat & $68,677,371,333$ & $62,111,209,165$ \\
\cline { 2 - 3 } & $\mathbf{8 3 , 2 9 4 , 9 3 4 , 7 7 5}$ & $\mathbf{6 8 , 6 7 7 , 3 7 1 , 3 3 3}$ \\
\hline
\end{tabular}

Sumber : PT. Pelindo III ( Persero )

Seperti yang terlihat pada laporan aktivitas diatas, periode tahun 2015 nampak ada alokasi bagian laba dari BUMN Induk dalam hal ini PT. Pelindo III (Persero) sebesar Rp. 23,880,315,340.Alokasi dari dana tersebut akan diakumulasikan dengan dana periode sebelumnya untuk melaksanakan program kemitraan dan bina lingkungan.

Dari kedua program tersebut yang telah dijalankan oleh PT. Pelindo III (Persero) Surabaya, tentunya tidak semudah dalam pelaksanaan di lapangan. Selalu ditemui kendala dan permasalahan yang dihadapi. Namun manajemen PT. Pelindo III (persero) Surabaya telah melakukan upaya-upaya dalam mengatasi permasalahan yang menjadi kendala dari pelaksanaan kedua program tersebut. Hal ini tergambar dari laporan posisi keuangan, menunjukkan bahwa pada tahun 2015 tingkat kolektibilitas pinjaman mencapai 48,52\% atau mencapai skor 2 dengan saldo piutang mitra binaan pada tahun 2015 sebesar Rp. 27,79 miliar,mengalami kenaikan jika dibandingkan dengan tingkat kolektibilitas pinjaman tahun 2014 yang mencapai sebesar 40,11\%. Berikut dibawah ini telah dibuat laporan Piutang Mitra binaan periode tahun 2015 berdasarkan umur piutang :

Tabel 5

Laporan Piutang Mitra Binaan Tahun 2015 PT. Pelindo III ( Persero )

\begin{tabular}{|c|l|r|r|r|}
\hline No & \multicolumn{1}{|c|}{ Uraian } & \multicolumn{1}{c|}{$\begin{array}{c}\text { Ak. } \\
\text { Penyisihan } \\
\text { Piutang }\end{array}$} & Piutang Neto \\
\hline 1 & Lancar :umur 0 $<30$ hari & $12,727,537,950$ & $156,211,374$ & $12,571,326,576$ \\
\hline 2 & $\begin{array}{l}\text { Kurang lancar : umur 31 hari }< \\
\text { 180 hari }\end{array}$ & $855,961,819$ & $84,779,782$ & $771,182,037$ \\
\hline 3 & Diragukan : Umur 181 hari $<270$ & & & \\
\hline
\end{tabular}




\begin{tabular}{|l|l|r|r|r|} 
& hari & $718,494,736$ & $123,789,420$ & $594,705,316$ \\
\hline 4 & Macet : umur > 270 hari & $23,732,867,075$ & $22,732,867,075$ & $1,000,000,000$ \\
\hline & Jumlah piutang usaha & $38,034,861,580$ & $23,097,647,651$ & $14,937,213,929$ \\
\hline
\end{tabular}

Sumber : PT. Pelindo III ( persero )

Menurut Manajemen PT. Pelindo III ( persero ), kendala yang dialami dalam pelaksanaan kedua program tersebut oleh manajemen, telah dirumuskan dalam 2 (dua) aspek yang berasal dari Mitra Binaan dan aspek Perusahaan. Berikut akan dijabarkan kendala yang dihadapi dan upaya mengatasi permasalahan dari kedua aspek tersebut.

\section{Aspek Mitra Binaan}

ketidak patuhan mitra binaan dalam melakukan pembayaran secara rutin tiap bulan. Upaya penyelesaiannya dilakukan antara lain :

a) Menumbuhkan dan meningkatkan kesadaran dan kedisiplinan pada mitra binaan dalam memenuhi kewajiban pembayaran angsuran secara rutin yang telah disepakati pada saat awal perjanjian melalui pengarahan dan pembinaan kepada mitra binaan dan setelah itu dievaluasi terhadap pembayaran angsuran kewajiban setiap bulan dan bila ada pembayaran yang macet sesegara mungkin untuk dilakukan perpanjangan masa angsuran ( rescheduling) kepada debitur yang mengalami kesulitan dalam usahanya dan memiliki itikad baik.

b) Melakukan monitoring dan intensifikasi kunjungan untuk penagihan angsuran rutin bulanan secara langsung ( door to door) kepada mitra binaan.

c) Disamping melakukan penagihan secara langsung terhadap mitra binaan, juga membentuk team khusus monitoring terhadap piutang yang disalurkan kepada mitra binaan sehingga apabila terjadi penggunaan dana penyaluran yang tidak sesuai peruntukan bisa di deteksi dini.

Aspek Perusahaan Penyalur Dana ( PT. Pelindo III)

Adanya penyaluran dana dalam kedua program ini, tentunya juga membuat beban operasional PT. Pelindo III cenderung tinggi dalam pelaksanaannya. Untuk mengatasi 
hal ini, tentunya diperlukan upaya -upaya dalam penyelesaiannya antara lain sebagai berikut :

a) Mengoptimalkan pelaksanaan survey secara kolektif

b) Mengutamakan penyaluran PKBL di sekitar wilayah perusahaan.

c) Mengoptimalkan SDM cabang dalam pelaksanaan survey program bina lingkungan.

\section{Kesimpulan Dan Saran}

\section{Kesimpulan}

Berdasarkan uraian di atas dapat dikemukakan beberapa kesimpulan yaitu sebagai berikut : Program Corporate Social Responsibility yang telah dijalankan oleh PT. Pelindo III Surabaya, diwujudkan dalam bentuk pelaksanaan program kemitraan/kerjasama dan program bina lingkungan. Program kemitraan/kerjasama merupakan program yang menjadi target pemerintah sebagai wujud kepedulian dan tanggung jawab Badan Usaha Milik Negara ( BUMN) terhadap perkembangan perekonomian, terutama bagi usaha mikro dan kecil di lingkungan perusahaan PT. Pelindo III, sedangkan program bina lingkungan merupakan program bentuk kepedulian PT. Pelindo III ( Persero ) terhadap kondisi sosial masyarakat sekitar perusahaan. Dalam pelaksanaan kedua program tersebut, PT. Pelindo III ( persero ) telah menetapkan mekanisme penyaluran program kemitraan dan bina lingkungan adalah dilakukan dengan metode Channeling atau metode penyaluran langsung yaitu penyaluran langsung oleh Pembina kepada para calon mitra binaan atau calon penerima bantuan yang telah mengajukan proposal terhadap kedua program PT. Pelindo III. Ditemui kendala dan permasalahan yang harus dihadapi oleh PT. pelindo III ( persero ), Namun manajemen PT. Pelindo III ( persero ) Surabaya telah melakukan upaya-upaya dalam mengatasi permasalahan yang menjadi kendala dari pelaksanaan kedua program tersebut. Hal ini tergambar dari laporan posisi keuangan, menunjukkan bahwa pada 
tahun 2015 tingkat kolektibilitas pinjaman mencapai 48,52\% atau mencapai skor 2 dengan saldo piutang mitra binaan pada tahun 2015 sebesar Rp. 27,79 miliar,mengalami kenaikan jika dibandingkan dengan tingkat kolektibilitas pinjaman tahun 2014 yang mencapai sebesar $40,11 \%$

\section{Saran}

Berdasarkan uraian di atas dapat dijelaskan beberapa saran dari penulis yang dapat dijadikan pertimbangan untuk kebijakan PT. Pelindo III (Persero) yaitu: Dalam pelaksanaan kedua program tersebut, hendaknya Manajemen harus selalu mengevaluasi kemajuan perkembangan kedua program tiap periode, disamping itu juga diupayakan pelatihan / pembinaan kepada mitra binaan dilaksanakan secara rutin dan teratur sesuai dengan program kerja. Dalam penyaluran terutama untuk program kemitraan, hendaknya team survey yang akan menyeleksi proposal yang masuk, hendaknya diikutkan dengan pendidikan dan pelatihan tentang penyaluran pemberian pinjaman dengan prinsip-prinsip Kehati-hatian ( Prudential Banking ) pada institusi perbankan atau mendatangkan trainer dari perbankan yang sudah professional dalam bidang pemberian kredit . Agar dalam penyaluran pinjaman tersebut tidak menjadi macet, hendaknya team survey juga melakukan monitoring terhadap penyaluran dana kepada mitra binaan, sehingga penggunaannya dapat lebih tepat sasaran sesuai dengan peruntukan.

\section{Daftar Pustaka}

Budiasih, I Gusti Nyoman. 2015. Pengaruh Good Corporate Governance Pada Nilai Perusahaan dengan Corporate Social Responsibility" E-Jurnal Akuntansi Universitas Udayana vol 13.

Fatihudin, Didin,2012.Metode Penelitian untuk Ilmu Ekonomi,Manajemen dan Akuntansi : dari Teori ke Praktek. Surabaya : penerbit PPs UM Surabaya

Hermawan,Sigit dan Maf'ulah,Afiyah Nurul.2014. "Pengaruh Kinerja Keuangan Terhadap Nilai Perusahaan Dengan Pengungkapan Corporate Social Responsibility sebagai variabel Pemoderisasi"Jurnal Dinamika Akuntansi.Vol. 6 (2) : hal 103 -118.

Kirana,Rosita Candra.2009. "Studi perbandingan pengaturan Tentang Corporate Social Responsibility di Beberapa Negara Dalam Perwujudan Prinsip Good Corporate Governance" Tesis Pascasarjana Universitas Sebelas Maret. Surakarta 
Nurlela, Rika dan Islahuddin. 2008."Pengaruh Corporate Social Responsibility terhadap Nilai Perusahaan dengan Prosentase Kepemilikan Manajemen sebagai Variabel Moderating : Studi Empiris pada Perusahaan yang terdaftar Pada Bursa Efek di Jakarta. Simposium Nasional Akuntansi ( SNA) XI Pontianak 2008.

Peraturan Menteri BUMN No. 05/MBU/2007 tentang Program Kemitraan dan Bina Lingkungan ( $P K B L$ )

Peraturan Menteri BUMN No. 03/MBU/12/2016 tentang Perubahan atas Peraturan Menteri Badan Usaha Milik Negara No. 09/MBU/2015 tentang Program Kemitraan dan Bina Lingkungan BUMN.

PT. Pelindo III. 2015. Buku Laporan Manajemen \& Keuangan Program Kemitraan dan Bina Lingkungan tahun 2015.

Undang-Undang Nomor 40 tahun 2007 tentang Perseroan Terbatas.

www.rahmatullah.net 


\section{Lampiran}

Hasil Wawancara dengan Pihak Keuangan PT Pelabuhan Indonesia III (Persero)

Nama Responden

Jabatan

Tempat wawancara

Tanggal wawancara

Pukul
: Lia Indi Agustiana

: Asisten Sekretaris Manajer Analisis dan Risiko Keuangan

: Kantor Pusat PT PELINDO III Surabaya, Jalan Perak Timur 610 Surabaya

: 13 Maret 2017

: $16.00-16.45$ WIB

Pertanyaan ke-1 : Bu, Saya mau tanya, dalam melakukan kegiatan CSR,apa wujud dan bentuk dari program CSR dari PT. Pelindo III ini ?

Pertanyaan ke-2 : Apa dasar hukum PT. Pelindo III melaksanakan Program CSR tersebut, bu?

Pertanyaan ke-3 : Terus bu, untuk mekanisme penyaluran dana pada program kemitraan dilakukan seperti apa ya ?

Pertanyaan ke-4 : Baik bu, akan saya pelajari.kalau tadi ibu bilang kalo program kemitraan dilakukan dengan pemberian bantuan dengan penyaluran dana kepada mitra binaan.Nah, untuk program bina lingkungan, perwujudan pelaksanaannya seperti apa ya bu?

Pertanyaan ke-5 : Dalam melakukan kedua program kerja diatas, apakah PT. Pelindo III juga membuat semacam informasi keuangannya, bu?

Lalu kalo menurut ibu sendiri, kira-kira berapa persen dana yang digunakan untuk CSR pada tahun 2016 yang telah terealisasi.

Pertanyaan ke-6 : Bu kalo saya baca sepintas, dalam laporan aktivitas itu ada salah satu uraian bahwa sumber dana untuk kedua program ini salah satunya ada yang berasal dari alokasi bagian laba dari BUMN Pembina. Memang kisaran berapa persen PT. Pelindo III mengeluarkan untuk csr, ya bu?

Pertanyaan ke-7 : Terus bu, biasanya kalau setahu ibu, selain dari alokasi bagian laba tahunan, dari mana lagi ya bu, biasanya BUMN itu mendapatkan sumber dana guna melakukan kegiatan csr nya? 
Pertanyaan ke-8 : Oh gitu ya bu, tadi seperti yang kita bahas diatas ada program kemitraan yang dimana PT. Pelindo III melakukan kegiatannya dengan menyalurkan dana kepada mitra binaan. Terus apa gak terjadi macetnya pinjaman dana tersebut ya bu, kan PT. Pelindo III bukan bergerak di bidang keuangan terutama dalam hal penyaluran dana tersebut.

Pertanyaan ke-9 : Apa kendala itu juga ada di program kemitraan saja ya bu ?bagaimana dengan program bina lingkungannya?

Pertanyaan ke-10 : Terus terakhir bu, apa sudah ada upaya untuk mengatasi kendalakendala tersebut dari kedua program ini, ya bu? 